\title{
Bacterial community survey of sediments at Naracoorte Caves, Australia
}

\author{
Eric M. Adetutu ${ }^{1}$, Krystal Thorpe ${ }^{1}$, Esmaeil Shahsavari ${ }^{1}$, Steven Bourne ${ }^{2}$, Xiangsheng \\ $\mathrm{Cao}^{1,3}$, Ramin Mazaheri Nezhad Fard ${ }^{1}$, Greg Kirby ${ }^{1}$, and Andrew S. Ball ${ }^{1}$
}

\begin{abstract}
:
Adetutu E.M., Thorpe K., Shahsavari E., Bourne S., Cao X., Fard R.M.N, Kirby G. and Ball A.S. 2012. Bacterial community survey of sediments at Naracoorte Caves, Australia. International Journal of Speleology, 41(2), 137-147. Tampa, FL (USA). ISSN $0392-6672$. DOI: http://dx.doi.org/10.5038/1827-806X.41.2.2

Bacterial diversity in sediments at UNESCO World Heritage listed Naracoorte Caves was surveyed as part of an investigation carried out in a larger study on assessing microbial communities in caves. Cave selection was based on tourist accessibility; Stick Tomato and Alexandra Cave (> 15000 annual visits) and Strawhaven Cave was used as control (no tourist access). Microbial analysis showed that Bacillus was the most commonly detected microbial genus by culture dependent and independent survey of tourist accessible and inaccessible areas of show (tourist accessible) and control caves. Other detected sediment bacterial groups were assigned to the Firmicutes, Actinobacteria and Proteobacteria. The survey also showed differences in bacterial diversity in caves with human access compared to the control cave with the control cave having unique microbial sequences (Acinetobacter, Agromyces, Micrococcus and Streptomyces). The show caves had higher bacterial counts, different 16S rDNA based DGGE cluster patterns and principal component groupings compared to Strawhaven. Different factors such as human access, cave use and configurations could have been responsible for the differences observed in the bacterial community cluster patterns (tourist accessible and inaccessible areas) of these caves. Cave sediments can therefore act as reservoirs of microorganisms. This might have some implications on cave conservation activities especially if these sediments harbor rock art degrading microorganisms in caves with rock art.
\end{abstract}

Keywords: caves; tourism; 16S rDNA; denaturing gradient gel electrophoresis

Received 7 November 2011; Revised 9 January 2012; Accepted 20 January 2012

\section{INTRODUCTION}

There has been a renewed focus from both scientific and economic points of view on microbial diversity in caves in recent times due to the increasing popularity of cave tourism. Tourists are attracted to caves because of their artefacts and unique features leading to substantial economic benefits for the tourism industry (Pulido-Bosch et al., 1997). These artefacts and features include rock art, Palaeolithic paintings and tools, speleothems and fossil deposits. However, changes in the caves' microclimatic conditions such as temperature, $\mathrm{CO}_{2}$, relative humidity and the caves' microbial composition and abundance are associated with human access. These changes can lead to damages of cave features and artefacts, the very

${ }^{1}$ School of Biological Sciences, Flinders University of South Australia, Adelaide, GPO Box 2100, Adelaide SA 5001 Australia. Corresponding author: Eric M. Adetutu (eric.adetutu@flinders. edu.au)

${ }^{2}$ Department for Environment and Heritage, P O Box 134, Naracoorte, South Australia 5271.

${ }^{3}$ College of Civil Engineering, Beijing University of Technology, Beijing, China 100124 factors attracting tourists (Russell \& MacLean, 2008; Bastian et al., 2009; Stomeo et al., 2009).

Cave microorganisms range from bacterial groups such as Proteobacteria, Actinobacteria, and Firmicutes to yeasts and saprophytic fungus such as Penicillium, Fusarium and Trichurus (Barton \& Jurado, 2007; Zhou et al., 2007; Bastian et al., 2009; Portillo et al., 2009a; Jurado et al., 2010; Adetutu et al., 2011; Vaughan et al., 2011). These microbial communities are affected by the geological nature of the caves, prevailing environmental conditions, soil or sediment factors and cave factors (configuration and use) (Ikner et al., 2007; Shapiro \& Pringle, 2010; Adetutu et al., 2011). Cave microorganisms in nutrient rich or limited environments (high and low energy caves) are metabolically versatile acquiring energy from cave compounds, gases and by oxidizing metals from rocks. Through these activities, these microorganisms play critical roles in caves' biogeochemical cycles and in the formation of cave features such as stalactites and stalagmites (Barton \& Jurado, 2007). This delicate microbial balance can however be disrupted by uncontrolled human access with adverse effects on the cave environment (Bastian et al., 2010). 
Most scientific investigations of cave environments have been focused on cave walls leading to abundant information on microbial diversity and function on cave walls (Gurtner et al., 2000; Portillo et al., 2009b; Stomeo et al., 2009; Martinez and Asencio, 2010; Pašić et al., 2010). This is because cave microbial activities are thought to take place on caves' rocky surfaces as most caves are devoid of substantial soil or sediment layer. Cave walls also bear rock art and Palaeolithic paintings which are the main tourist attractions but are highly susceptible to microbial damage (Schabereiter-Gurner et al., 2002; Bastian et al., 2010). Cave sediment or soils (Park et al., 2000) are poorly studied and where present should also be subject to scientific investigations for a variety of reasons.

Cave sediments are usually the primary recipient of exogenous materials associated with human access to caves and can be good indicators of the impact of human access on cave environments. In addition, the movement of microorganisms would occur in a cycle between the cave walls and sediments; sediment microorganisms are therefore part of the cave's ecosystem. Cave sediments could also serve as a reservoir of microorganisms (such as rock art degrading organisms) which could complicate potential conservation work focused on walls of caves with sediments. In addition to this, bacterial surveys are usually carried out in areas of tourist access or activity in show caves with non tourist accessible caves being used as controls. Consequently, these surveys only reflect the partial bacterial diversity in these areas. However, a survey that includes samples obtained from both tourist accessible and inaccessible areas of a cave would give a more accurate and comprehensive picture of bacterial diversity.

Naracoorte Cave Park (UNESCO World Heritage Listed Site) in South Australia is a popular cave park because of its extensive fossil deposits, speleothems and accessibility for adventure caving. Importantly, some of the caves in this park have extensive sediment deposits which have not been studied in detail. These caves therefore offer a good opportunity for studying microbial diversity in cave sediments. This study was carried out as part of a large study commissioned by the Naracoorte Cave Management to assess the impact of tourism on the cave environment. This involved carrying out a survey of bacterial diversity in tourist accessible areas and inaccessible areas of selected high impact caves using culture dependent and independent techniques (PCR-DGGE-Sequencing). Assessment of the bacterial community structures in these areas will provide more information on their diversity in cave sediments and reveal any change associated with human access.

\section{MATERIALS AND METHODS}

\section{Sampling site and sample collection}

Three caves (Alexandra, Stick Tomato and Strawhaven) were selected for investigations based on tourist access and cave configurations. Sediment samples (up to $100 \mathrm{~g}$ ) were collected from multiple locations in sections of the caves designated as tourist traffic route by digging $5 \mathrm{~cm}$ deep into the sediment. Sediment samples were also obtained from areas of the caves that were inaccessible to tourists.

\section{The caves}

Alexandra Cave has speleothems, mirror pools and straw clusters (thin stalactites) and is accessible by guided tour with up to 18,000 annual visits. Alexandra Cave has two entrances, each with a locked door and has no twilight zone. The main door opens into a 3-4 m long concrete staircase leading to the tourist track. Samples were obtained in the "dark zone" of the cave $(6 \mathrm{~m}$ from the bottom of the staircase) in 4-5 $\mathrm{m}^{2}$ grids (D1-D3) as shown in Fig. 1A. Sediment samples from tourist inaccessible areas were obtained from an alcove about $15 \mathrm{~m}$ away from the cave's entrance in $4-5 \mathrm{~m}^{2}$ grids (ND1-ND3) shown in Fig. 1A. Multiple sediment samples ( $=12)$ were collected in each grid with sediments from each grid being pooled (Fig. 1A). Stick Tomato Cave is a multiple use cave (self guided tour and adventure caving) with up to 20,000 annual visits. It has two open entrances ( $>3 \mathrm{~m}$ wide), with the entrance in the adventure caving section capturing large amounts of water and detritus during storm events. Stick Tomato Cave has twilight zone of $\sim 20 \mathrm{~m}$ into the cave (Fig. 1B) and sediment samples were obtained on the cave's tourist path from about $6 \mathrm{~m}$ into dark zone ( $26 \mathrm{~m}$ into the cave) in three grids. Sediment samples were also obtained from tourist inaccessible areas in the grids (ND1-ND3) shown in Fig. 1B. Multiple sediment samples were collected in 4-5 $\mathrm{m}^{2}$ grids with the approximate location of each grid depending on the topography of the cave floor. Sediment samples from each grid were pooled together to represent the microbial community in that area for ease of analysis.Strawhaven is a research cave inaccessible to tourists and samples were obtained from about 12 $\mathrm{m}$ into the cave in areas shaded in Fig. $1 \mathrm{C}$.

\section{Plate count and microbial isolation}

Sediment samples from tourist accessible and inaccessible areas were serially diluted in $0.01 \mathrm{M}$ phosphate buffered saline (pH 7.4) (Sigma, St Louis, MO, USA) at 10, 100 and 1000 fold dilutions. Aliquots from each dilution series were inoculated into sterile dilute Nutrient Agar (1:100) (Oxoid Ltd, Hampshire, England) plates for the detection and enumeration of oligotrophic cave bacteria (Portillo et al., 2009a). These plates were incubated at $25 \pm 1{ }^{\circ} \mathrm{C}$ for up to four weeks after which the microbial colonies on each plate were counted and expressed as the Log of the total number of colony forming units (CFU). Bacterial isolates on these plates were then grouped based on morphological characteristics, purified and subject to molecular analysis.

\section{DNA Extraction and PCR}

DNA was extracted from replicate cave sediments $(0.25 \mathrm{~g})$ using the PowerSoil ${ }^{\mathrm{TM}}$ DNA extraction kit (Mo Bio Laboratories Inc, Carlsbad, CA, USA) according to the manufacturer's instructions. 16S rDNA amplification was carried out using primer pair $341 \mathrm{~F}$ GC and 518R (Muyzer et al., 1993). 


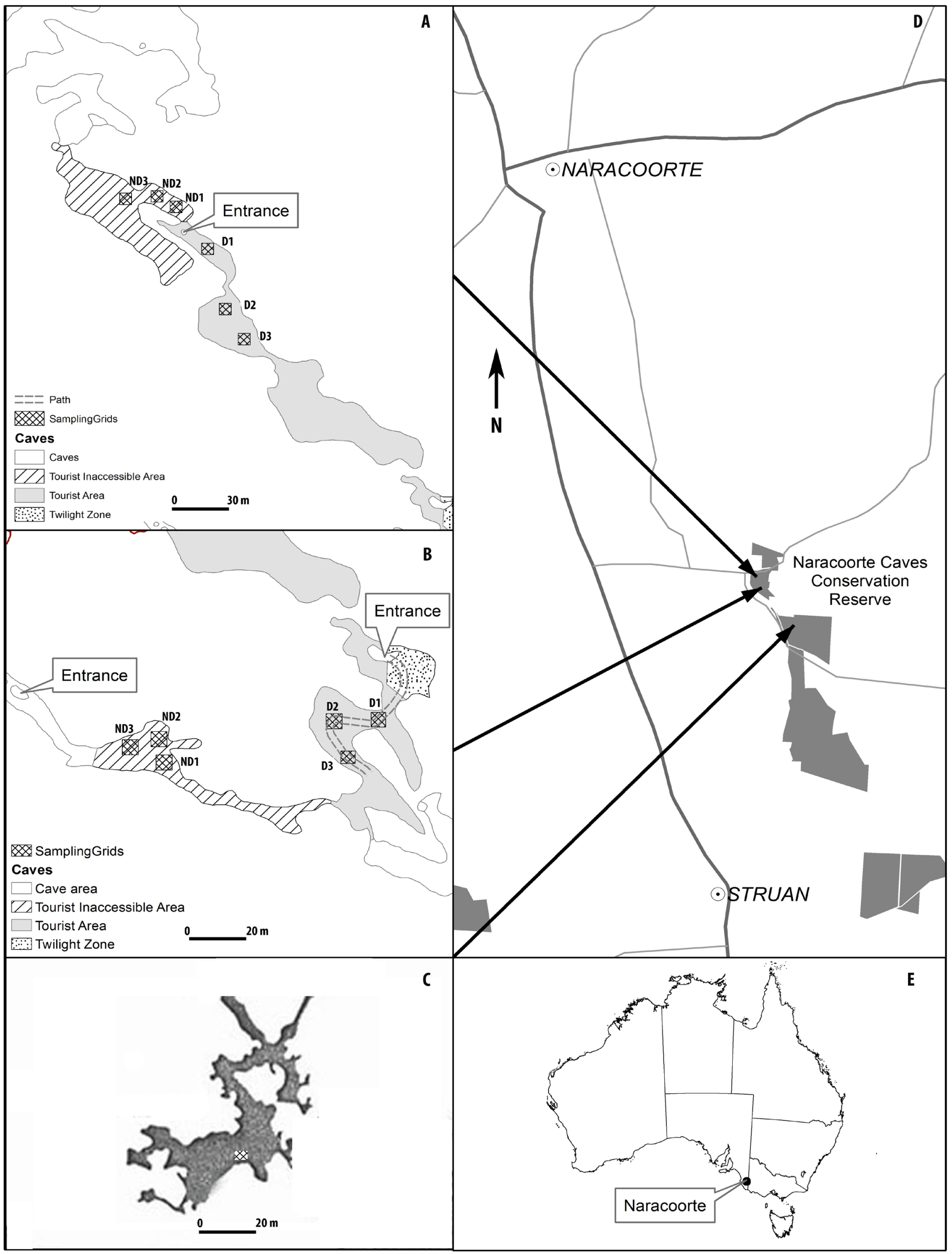

Fig. 1. A map of Naracoorte showing the caves studied and approximates areas where samples were taken. $A=A l e x a n d r a ~ C a v e, B=S t i c k$ Tomato Cave, C = Strawhaven Cave, D = location of Naracoorte Caves and E = location of Naracoorte in Australia. D1-D3 = areas accessible to tourists and NDI-ND3 = areas inaccessible to tourists. Sampling grids and shaded areas (c) are not drawn to scale and are approximate sampling points. 


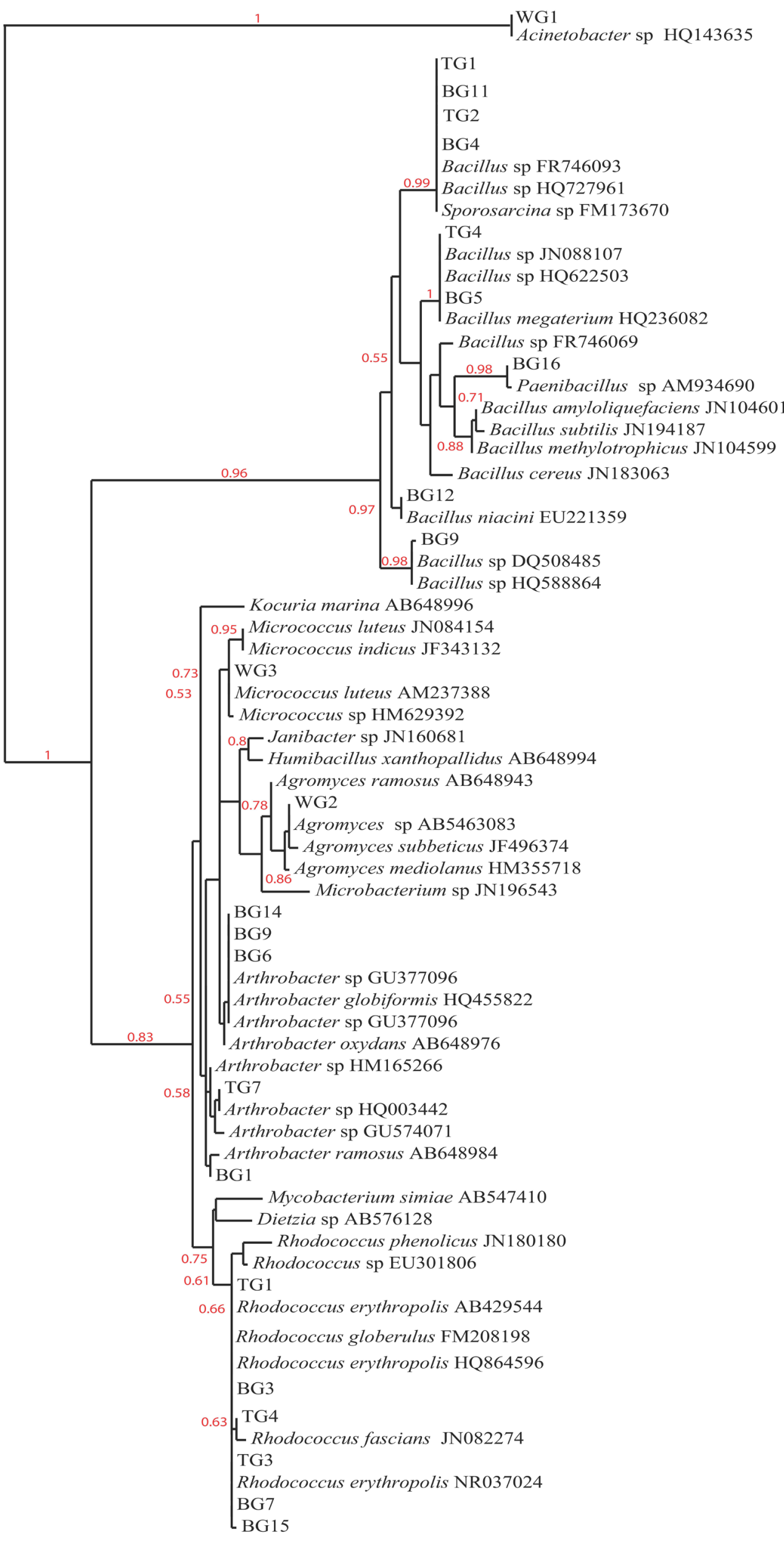

Proteobacteria

Firmicutes

Actinobacteria

Fig. 2. Phylogenetic trees of cave phylotypes derived from pure culture isolates (a) and selected excised DGGE bands (b) in Stick Tomato, Strawhaven and Alexandra caves. For (a), tree was constructed from 1100 1300 nucleotide positions while the tree in was constructed from 200-280 nucleotide positions (b). Distances were calculated with the maximum likelihood model in PhyML. Only partial sequences that could be aligned were used for both trees and bootstrap values $\geq 0.50$ are shown. 
DNA was also extracted from pure bacterial cultures by flooding replicate plates with $5 \mathrm{ml}$ of sterile phosphate buffer, homogenising plate cultures with sterile spreaders and transferring aliquots into sterile $1.5 \mathrm{ml}$ Eppendorf tubes. Samples were pelleted by centrifugation at $12000 \times \mathrm{g}$ for $15 \mathrm{~min}$. The supernatant was discarded and the pellet was transferred aseptically to the PowerSoil PowerBead tubes for DNA extraction. The extracted DNA $(2 \mu \mathrm{l})$ were subjected to PCR using primers $63 \mathrm{~F}$ and $1389 \mathrm{R}$ (Osborn et al., 2000).The thermocyling condition used for $63 \mathrm{~F}$ and $1389 \mathrm{R}$ reactions involved an initial denaturation for $5 \mathrm{~min}$ at $94^{\circ} \mathrm{C}$, followed by 30 cycles of $94^{\circ} \mathrm{C}$ for $1 \mathrm{~min}, 55^{\circ} \mathrm{C}$ for $1 \mathrm{~min}$ and $72^{\circ} \mathrm{C}$ for $2 \mathrm{~min}$ and a final extension of $72^{\circ} \mathrm{C}$ for $10 \mathrm{~min}$.

\section{DGGE, community profiling and analysis}

Denaturing Gradient Gel Electrophoresis analysis of $16 \mathrm{~S}$ rRNA genes was carried out with 40 to $60 \%$ urea-formamide denaturant gradient (9\% polyacrylamide gels), run for $20 \mathrm{~h}$ at $60{ }^{\circ} \mathrm{C}$ and $60 \mathrm{~V}$. DGGE gels were silver stained (Girvan et al., 2003) and scanned. DGGE gels were analysed with Phoretix 1D software (Non Linear Dynamics, Durham, USA) to generate similarity clusters using the unweighted pair group method with mathematical averages (UPGMA). Shannon index (') was also calculated from DGGE profiles as described by Girvan et al., (2003) using the formula $H^{\prime}=-\sum$ $\mathrm{p}_{i}$ LN $\mathrm{p}_{i}$. Principal component analysis (PCA) was carried out using SPSS version 19 on the matrix data obtained from Phoretix 1D analysis (TL 120). Pareto Lorenz (PL) curves were used to estimate evenness within the microbial community. Bands were ranked from high to low based on their intensities. The normalized cumulative bands (numbers) were plotted on $\mathrm{x}$-axis while their respective normalized cumulative intensities were plotted on the y-axis to draw a PL curve. Intercept was set at $20 \%$ of population $(0.2 \mathrm{x}$-axis) to determine proportional cumulative intensity and perfect evenness drawn at $45^{\circ}$ (Marzorati et al., 2008). Statistical significance was determined in samples within or between caves by either T test or analysis of variance (ANOVA) and Tukey tests on SPSS.

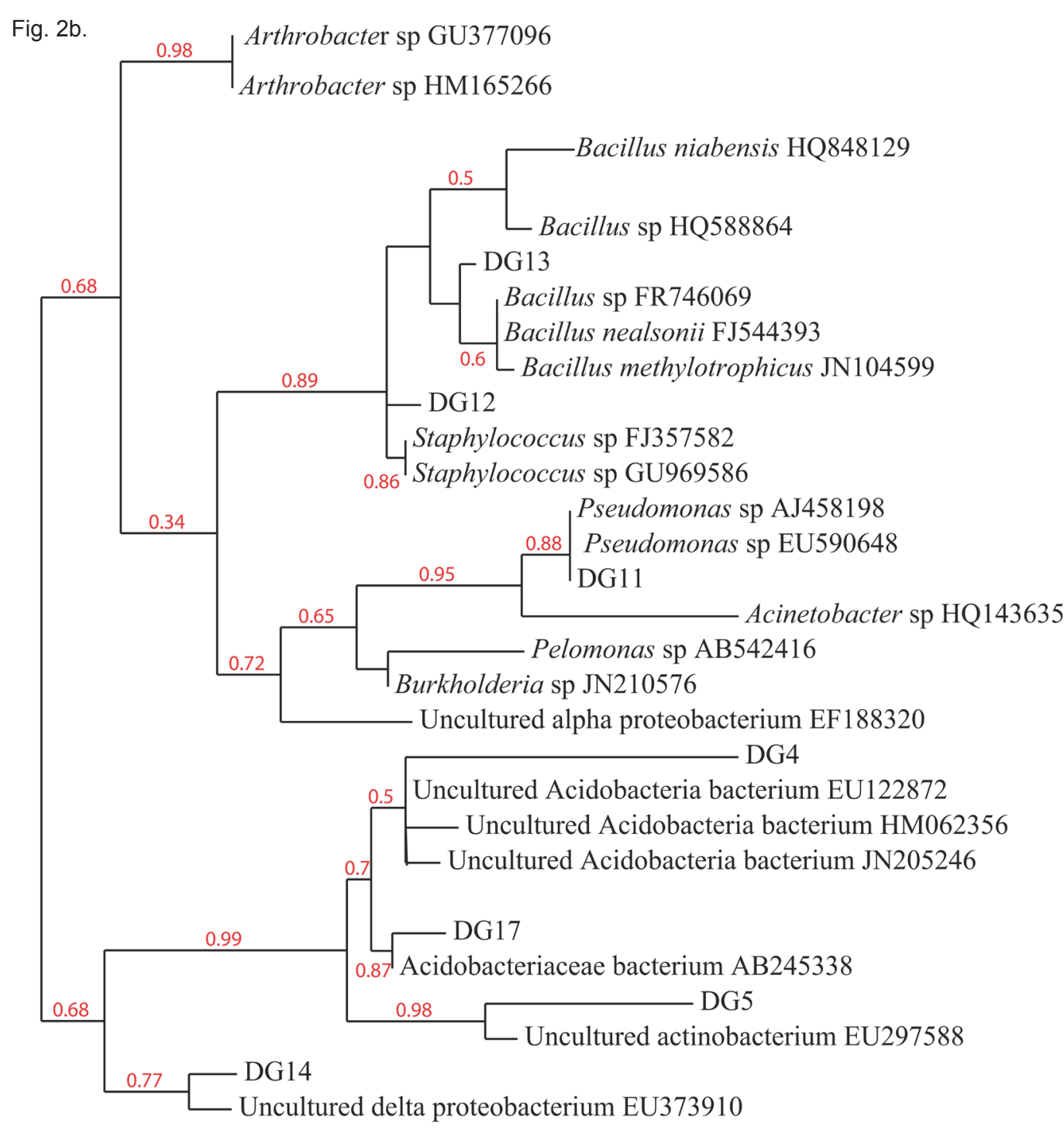

Actinobacteria

Firmicutes

Proteobacteria

Acidobacteria

Actinobacteria

Proteobacteria 


\section{Sequence and phylogenetic analysis}

Dominant bands (numbered) on DGGE gels were aseptically excised and the DNA eluted (Patil et al., 2010). Eluted DNA was then cleaned up by repeated PCR, band excision and DGGE (using a narrower gradient range), in order to get pure bands for sequencing. Purified DGGE bands and amplicons from pure cultures PCR were sequenced and analysed as described by Adetutu et al., (2011) with the aligned sequences being submitted to BLASTN from GenBank (hhtp://www.ncbi.nlm.nih.gov (see Table 1 for accession number) for generating similarity searches. Sequences from the database that matched the unknown sequence data submitted were aligned with CLUSTALW2 (http://www.ebi.ac.uk/Tools/ msa/clustalw2/) module and used to calculate pair wise evolutionary distances between the sequences. Phylogenetic trees were then constructed and viewed using maximum likelihood algorithm and Tree Dyne in PhyML (Dereeper et al., 2008).

\section{RESULTS \\ Culture Dependent Analysis}

The total viable bacterial counts in $0.01 x$ Nutrient Agar are shown in Table 1.The disturbed (tourist accessible) regions of Stick Tomato and Alexandra Caves had consistently higher bacterial counts than their non disturbed areas (tourist inaccessible). The non disturbed areas of these caves however had a higher bacteria count than the control Strawhaven Cave. Actinomycetes putatively identified as Streptomyces (data not shown) were detected in Strawhaven and absent in other caves (Table 1).Culture based survey also showed that both Stick Tomato and Alexandra Caves largely contained similar bacterial genera (such as Bacillus) in both tourist accessible and inaccessible areas with a few exceptions. For example Arthrobacter sp. is only found in Stick Tomato (non disturbed) while being present in all sampling areas in Alexandra (Table 2). These genera were assigned to the Firmicutes and Actinobacteria (Table 2 and Fig. 2a). However a different set of microbial genera which included Acinetobacter (Proteobacteria), Agromyces and Micrococcus (Actinobacteria) species were detected in Strawhaven Cave (Table 2 and Fig. 2a). Fig. $2 \mathrm{~b}$ however shows the phylogenetic tree of sequences from culture independent analysis.

\section{Culture Independent Analysis}

Detailed examination of the cave bacterial community cluster showed that the bacterial banding patterns in Stick Tomato and Alexandra Cave were substantially different from that of the control Strawhaven Cave (Fig. 3a). Cluster analysis (UPGMA dendrogram) also showed that the bacterial banding pattern in tourist accessible areas of Stick Tomato Cave was different from that of areas not accessible to tourists. This was in contrast to the trend observed in Alexandra Cave where the banding patterns in these two areas were similar. Principal component analysis of these caves also showed four dissimilar groups based on caves and access to tourists with tourist accessible and inaccessible areas being grouped together only in Alexandra Cave (Fig. 3b). Sequence analysis of some of the bands unique to tourist accessible areas showed that they were most similar to uncultured Acidobacteria and alpha proteobacteria groups (Stick Tomato) with sequences most similar to Pelomonas (beta proteobacteria) being unique to the inaccessible areas (Table 3). Other bacterial species detected in other caves are also shown in Table 3 with Bacillus being detected in all the caves irrespective of sampling area. The Phylogenetic tree showed that four different bacterial groups (Actinobacteria, Firmicutes, Proteobacteria and Acidobacteria) were detected in these selected caves at Naracoorte (Table 3 and Fig. 2b). However, only two of these groups (Firmicutes and Proteobacteria) were detected in the Strawhaven Cave (control) (Table 3). Pareto Lorenz Curve distribution patterns for caves' bacterial communities also showed distinct differences between the communities in Stick Tomato Cave (74-76\%) and Alexandra Cave (55-58\%) (Fig. 4). The bacterial community in Stick Tomato therefore had less evenness and different functional organization to Alexandra. Bacterial community diversity analysis using Shannon Weaver Diversity $\left(H^{\prime}\right)$ only showed significant differences between Stick Tomato and Strawhaven Cave (ANOVA, $\mathrm{P}<0.05$ ) (data not shown).

Table 1. Total viable count of bacteria cells in 0.01 strength Nutrient Agar in tourist accessible and inaccessible areas of selected caves at Naracoorte.

\begin{tabular}{lccccc}
\hline & \multicolumn{5}{c}{ Log CFU g ${ }^{-1}$ soil } \\
\cline { 2 - 6 } & \multicolumn{2}{c}{ Stick Tomato } & \multicolumn{2}{c}{ Alexandra } & Strawhaven \\
\cline { 2 - 6 } Microorganism & D & ND & D & ND & ND \\
\cline { 2 - 6 } Bacteria & $5.31 \pm 0.05^{\mathrm{a} *}$ & $4.71 \pm 0.07^{\mathrm{a} *}$ & $5.38 \pm 0.10^{\mathrm{b} *}$ & $4.93 \pm 0.19^{\mathrm{b} *}$ & $1.52 \pm 0.66^{*}$ \\
Actinomycetes & - & - & - & - & $2.22 \pm 0.90$ \\
\hline
\end{tabular}

Note: - none detected. Values shown are means of log CFU of 3 replicate plates. Same letter with asterisk are significantly different from each other. ${ }^{{ }^{*}}$ and ${ }^{\mathrm{b} *}$ are significantly different from ${ }^{*}$. D- tourists accessible areas, ND- areas inaccessible to tourists. 
Table 2. Summary and location of bacterial isolates detected in selected caves from Naracoorte Park (culture based isolations)

\begin{tabular}{lcccc}
\hline Phylotype & Cave & $\begin{array}{c}\text { Division } \\
\text { (or subdivision) }\end{array}$ & Nearest taxon & Similarity(\%) \\
\hline TG1 & STD & Firmicutes & Bacillus sp HQ727966 & 99 \\
TG2 & STD & Firmicutes & Bacillus sp HQ727961 & 99 \\
TG3,8,BG3 & STD\&STND & Actinobacteria & Rhodococcuserythropolis HQ864596 & 99 \\
TG4 & STD & Firmicutes & Bacillusmegaterium HQ236082 & 100 \\
TG5 & STD & Actinobacteria & Rhodococcus sp EU301806 & 98 \\
TG6 & STD & Firmicutes & Bacillus sp HQ588864 & 98 \\
TG7 & STND & Actinobacteria & Arthrobacter sp HQ003442 & 100 \\
WG1 & SND & Proteobacteria & Acinetobacter sp HQ143635 & 100 \\
WG2 & SND & Actinobacteria & Agromyces sp AB546308 & 100 \\
WG3 & SND & Actinobacteria & Micrococcusluteus AM237388 & 100 \\
BG1 & AD & Actinobacteria & Arthrobacter sp HM165266 & 100 \\
BG2 & AD & Firmicutes & Bacillus sp FR746069 & 99 \\
BG4 & AD & Firmicutes & Bacillus sp FR746093 & 100 \\
BG5 & AD & Firmicutes & Bacillus sp HQ622503 & 100 \\
BG6,9 & AD\&AND & Actinobacteria & Arthrobacter sp GU377096 & $99-100$ \\
BG7 & AND & Actinobacteria & Rhodococcuserythropolis NR0370241 & 99 \\
BG8 & AND & Firmicutes & Bacillus sp DQ508485 & 100 \\
BG10 & AND & Actinobacteria & Arthrobacterglobiformis EU333890 & 95 \\
BG11 & AND & Firmicutes & Bacillussimplex FJ999940 & 99 \\
BG12 & AND & Firmicutes & Sporosarcina FM173670 & 99 \\
BG13 & AND & Firmicutes & Bacillusniacine EU221359 & 99 \\
BG14 & AND & Actinobacteria & Arthrobacterglobiformis HQ455822 & 100 \\
BG15 & AND & Actinobacteria & Rhodococcuserythropolis AB429544 & 98 \\
BG16 & AND & Firmicutes & Paenibacillus sp AM934690 & 98 \\
& & & &
\end{tabular}

Note: STD- Stick Tomato Disturbed (tourists accessible areas), STND- Stick Tomato Non Disturbed (areas inaccessible to tourists), ADAlexandra Disturbed (tourists accessible areas), AND- Alexandra Non Disturbed (areas inaccessible to tourists), SND-Strawhaven Non Disturbed (control; inaccessible to tourists).

Table 3. Summary and location of bands excised from 16S rRNA based DGGE profiles of selected caves from Naracoorte Park.

\begin{tabular}{|c|c|c|c|c|}
\hline Phylotype & Cave & $\begin{array}{c}\text { Division } \\
\text { (or subdivision) }\end{array}$ & Nearest taxon & ilarit \\
\hline DG1 & STND & Betaproteobacteria & Pelomonas sp AB542416 & 92 \\
\hline DG2 & STD & Acidobacteria & Uncultured acidobacteria HM062356 & 98 \\
\hline DG3 & STD & Acidobacteria & Uncultured Acidobacteria EU122872 & 95 \\
\hline DG4 & STD & Acidobacteria & Uncultured Acidobacteria EU979056 & 97 \\
\hline DG5 & STD \& STND & Actinobacteria & Uncultured Actinobacteria EU300539 & 93 \\
\hline DG6 & STD STND, AD AND & Firmicutes & Bacillus sp HM366466 & 92 \\
\hline DG 7 & STD \& STND & Firmicutes Uncultured & Bacillus sp EF074890 & 98 \\
\hline DG8 & STD & Alphaproteobacteria & Uncultured alphaproteobacteria EF188320 & 99 \\
\hline DG9 & SND & Alphaproteobacteria & Sphingomonas sp AB288313 & 100 \\
\hline DG10 & SND & Firmicutes & Bacillus sp EU589406 & 100 \\
\hline DG11 & SND & Gammaproteobacteria & Pseudomonas sp EU590648 & 98 \\
\hline DG12 & SND & Firmicutes & Uncultured bacteria JF239301 & 98 \\
\hline DG 13 & SND & Firmicutes & Bacillus nealsonii FJ544393 & 93 \\
\hline DG14 & AD \& AND & Deltaproteobacteria & Uncultured Deltaproteobacterium EU373910 & 93 \\
\hline DG15 & AND & Bacteria & Uncultured bacteria FJ409452 & 90 \\
\hline DG16 & AND & Firmicutes & Uncultured bacteria EF072331 & 98 \\
\hline \multirow[t]{2}{*}{ DG 17} & $\mathrm{AD}$ & Firmicutes & Bacillus sp FJ373035 & 98 \\
\hline & & Acidobacteria & Acidobacteria AB245338 & 98 \\
\hline DG18 & $\mathrm{AD} \& \mathrm{AND}$ & Alphaproteobacteria & Uncultured alphaproteobacteria HM057723 & 94 \\
\hline
\end{tabular}

Note: STD- Stick Tomato Disturbed (tourists accessible areas), STND- Stick Tomato Non Disturbed (areas inaccessible to tourists), AD- Alexandra Disturbed (tourists accessible areas), AND-Alexandra Non Disturbed (areas inaccessible to tourists), SND-Strawhaven Non Disturbed (control; inaccessible to tourists). 


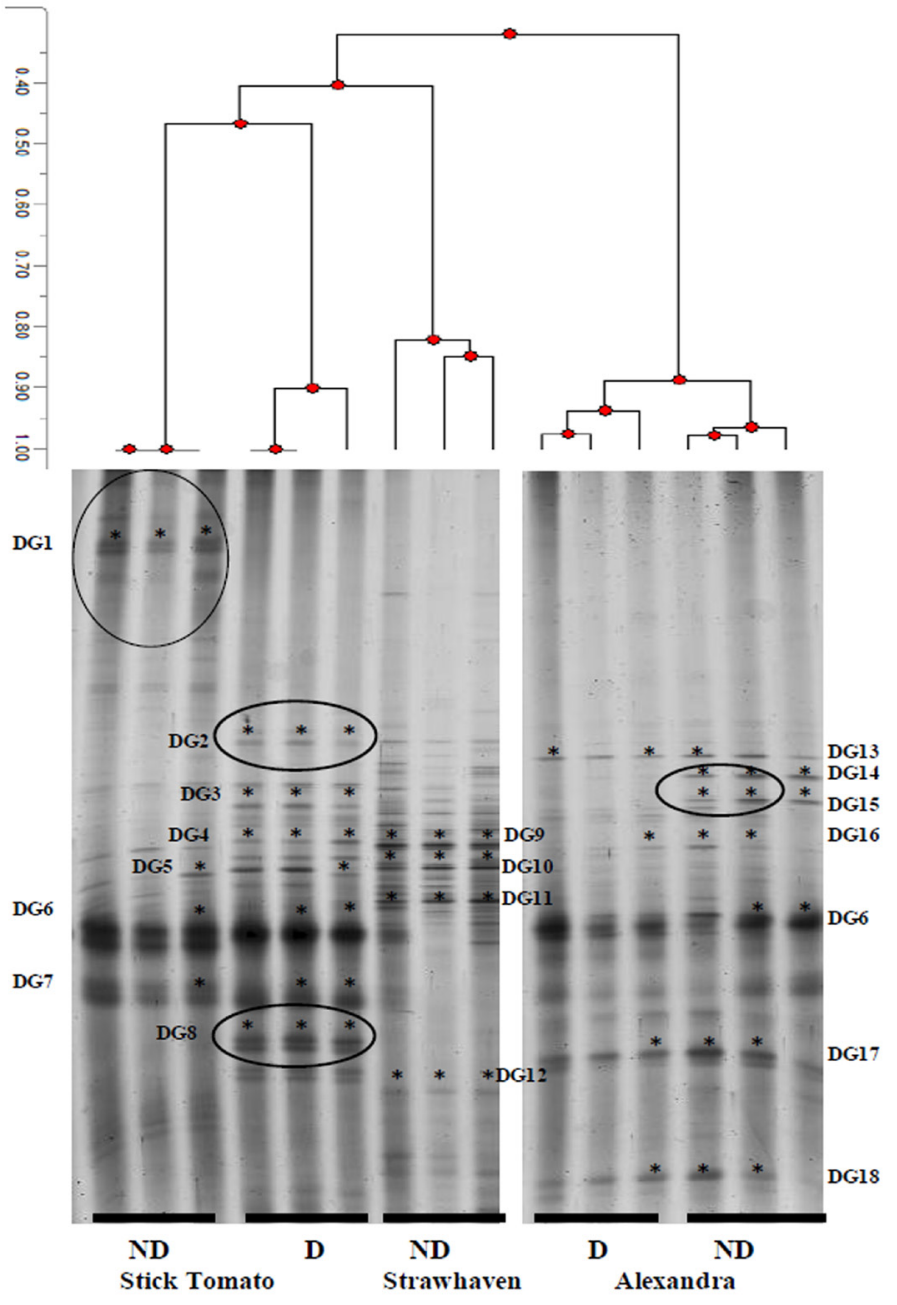

\section{DISCUSSION}

\section{Culture independent and dependent survey}

The most commonly detected bacterial group in tourist and non tourist accessible areas of show and control caves by culture dependent and independent (except in Strawhaven) was Firmicutes. Although Firmicutes (Bacillus sp) along with Escherichia coli and Staphylococcus have been considered as indicators of human impact on caves (Lavoie \& Northup, 2006), their detection in the community profiles of all the caves suggested that they were indigenous to these caves. Bacillus sp have been isolated in caves (Fernandez-Cortes et al., 2011; Urzi et al., 2010) and their dispersal throughout the cave ecosystem is enhanced by their abilities to produce spores. Phylogenetic trees of other DGGE sequences showed that these can be grouped under Acidobacteria, Actinobacteria and Proteobacteria and similar groups have also been detected on cave walls (Schabereiter-Gurtner et al., 2002; 2004; Ikner et al., 2007; Urzì et al., 2010). Cave walls, cave animals, insects and human visitors (Chelius \& Moore, 2004; Portillo et al., 2009b) are therefore potential sources of bacterial species in cave sediments.

Bacteria play important roles in the biogeochemical cycles of caves (Zhou et al., 2007) and have been implicated in the deterioration of cave features. Some members of the Proteobacteria group are associated with the deterioration of

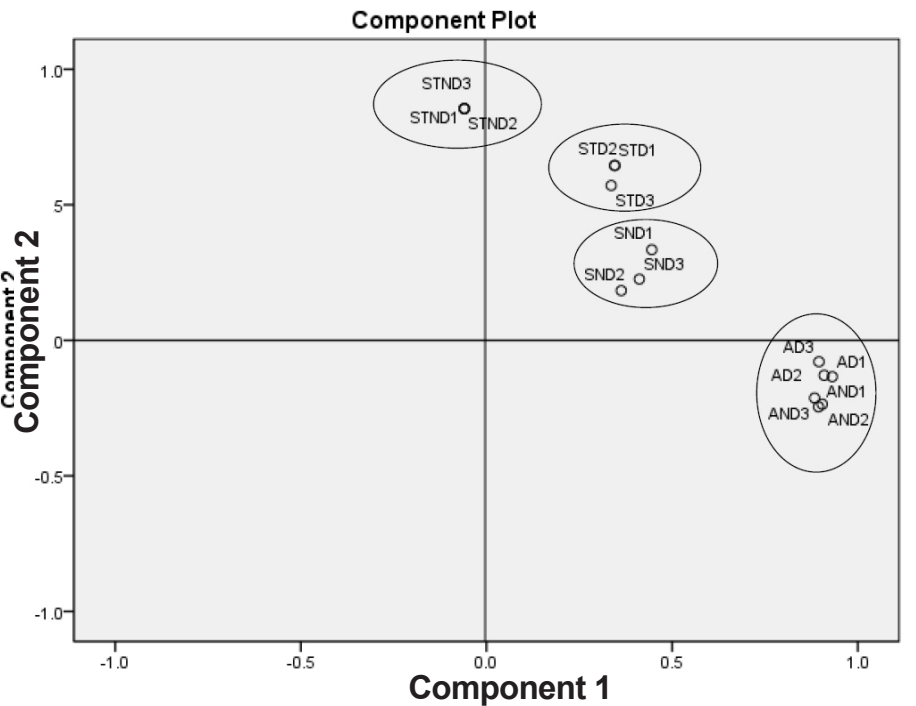

Fig. 3. UPGMA dendrogram of bacterial community (a) and principal component analysis (PCA) based on 16S rRNA DGGE profiles of selected caves at Naracoorte National Park. Dendrogram has been generated with Phoretix software (Non-Linear Dynamics, Durham, USA) while PCA was carried out with SPSS 19. For (a), bands peculiar to specific areas in each cave are circled while excised bands are below the asterisks. ND refers to tourist inaccessible areas while D refers to tourist accessible areas. For (b), STND1STND3, SND1-SND3 and AND1-AND3 refer to areas not accessible to tourists in Stick Tomato, Strawhaven and Alexandra Caves respectively while STD-STD3 and AD1-AD3 refer to tourist accessible areas in Stick Tomato, and Alexandra caves.

Palaeolithic paintings (Portillo et al., 2009b) while some Firmicutes (Bacillus) are involved in calcite precipitation (stalactites formation) in caves (Baskar et al., 2006). Calcite precipitation can damage parietal markings (such as prehistoric human markings) on moonmilk reducing their touristic potential. The detection of bacterial species which are members of these groups in cave sediments at Naracoorte means that sediments can potentially act as reservoirs. The abilities of these detected groups to degrade cave artefacts (painting) were not assessed in this study because none of the caves investigated in this study had rock art.This finding would probably be more important in caves with paintings where much of the microbial investigations have been on cave walls with a view of preserving such paintings (Portillo et al., 2009b; Stomeo et al., 2009). Eliminating microbial groups (especially when found to be rock art degraders) from the wall might only bring limited success as the floor (and sediments when present) could be reservoirs of these microbial groups.

Culture based techniques (despite their limitations) have been used to study cave microorganisms (Stomeo et al., 2009; Campbell et al., 2011; Adetutu et al., 2011). Combining culture based data with data from culture independent techniques such as DGGE (which sometimes detect only the top $1 \%$ population) (Muyzer et al., 1993) can give a more detailed picture of microbial diversity in cave sediments. A good example of this is Alexandra Cave in which Bacillus, Acidobacteria, uncultured 


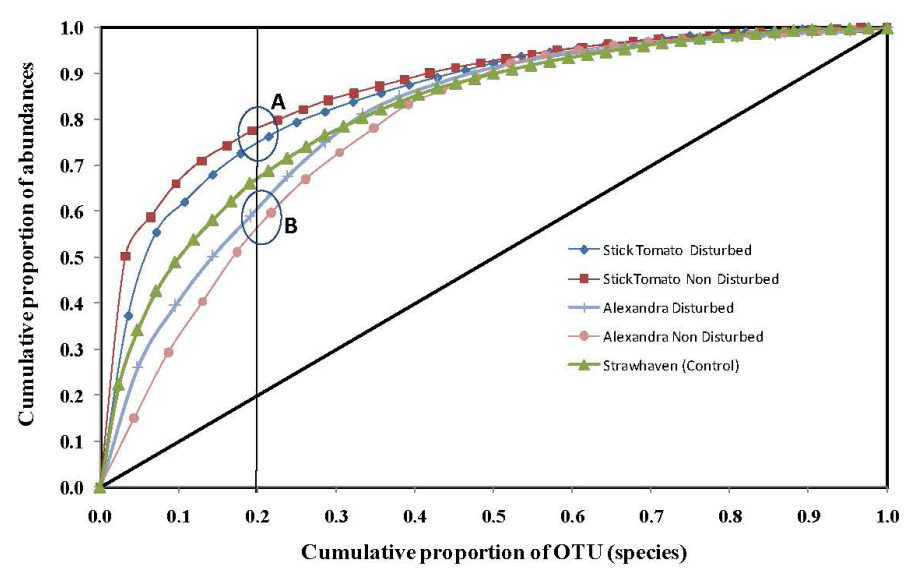

Fig. 4. Pareto-Lorenz distribution curves derived from 16S rRNA genes based DGGE profiles of areas accessible (disturbed) and inaccessible (non-disturbed) in selected caves at Naracoorte Park. The vertical line is plotted at $0.2 \mathrm{x}$-axis in order to compare different Pareto values while the 45 degree diagonal line represents the perfect evenness of a community. Letters $A$ and $B$ indicate different ranges of Pareto values observed at each cave.

Alpha proteobacteria and Delta proteobacteria were detected on the caves' DGGE profiles. Additional genera such as Rhodococcus and Arthrobacter were observed in culture based assays.A similar trend was observed in Stick Tomato Cave. Phylogenetic analysis however, indicated that these bacterial species largely belonged to similar taxa (Firmicutes, Actinobacteria, Proteobacteria and Acinetobacteria) showing some agreement between culture dependent and independent assays. Different microbial genera (Acinetobacter, Agromyces, Micrococcus and Streptomyces) were also isolated in the control cave (Strawhaven) compared to the two show caves. The observed differences in the species between the tourist accessible caves and the control cave might be related to edaphic (sediment) factors, cave use and human access.

\section{Tourist accessible and inaccessible areas}

In addition to differences in bacterial species, the cluster analysis and principal component analysis groupings of the show caves were also substantially different from that of Strawhaven Cave. The bacterial counts in Stick Tomato and Alexandra Caves were significantly higher than that of Strawhaven $(\mathrm{P}<0.05)$ with the bacterial diversity $\left(H^{\prime}\right)$ of Stick Tomato Cave being significantly different from Strawhaven's (data not shown). Changes in bacterial community composition and number have been associated with tourism (Ikner et al., 2007; Shapiro \& Pringle, 2010). Higher ratios of coliform to total bacterial count have also been linked to anthropogenic pollution of show caves (Mulec et al., 2012). Tourists can bring in exogenous microorganisms from the outside environment and other caves along with substances such as hair, lint, dead skin cells and skin oils (potential nutrients for cave microorganisms) (Barton, 2006) causing changes in microbial communities. The presence of exogenous (foreign) organic matter in caves has been shown to alter caves' bacterial abundance and diversity compromising the integrity of the indigenous bacterial community (Chelius et al., 2009). Consequently, the differences between the two show caves and control cave (Strawhaven) might be associated with human access, although other environmental factors such as sediment microbial community heterogeneity could have played some roles in this.

The observed differences in the Pareto-Lorenz (PL) distribution curves of Stick Tomato Cave and Alexandra Cave showed that the bacterial community's evenness differed between caves. The higher "within cave variation" (cluster patterns and principal component groupings) between tourist accessible and inaccessible areas of Stick Tomato as compared to Alexandra also suggested that other factors such as cave use and configurations were affecting bacterial diversity. The airflow system in caves (which was not investigated in this study) can also influence bacterial distribution in caves. The airflow system is affected by cave volume, differences in temperature and pressure between the cave and outside environment and also by the orientation of cave openings (Pflitsch \& Piasecki, 2003).

Stick Tomato as an open access cave (without doors) will have a higher input of exogenous materials, possibly different temperature gradient and airflow pattern compared to a closed cave (with doors) like Alexandra. These factors could have affected the spread of cave bacteria in caves. Consequently, it is possible that convective air circulation (FernandezCortes et al., 2006) common in closed caves like Alexandra resulted in a more even spread of bacteria within the cave environment and might explain the similarity in bacterial cluster patterns in the different areas of this cave.

\section{CONCLUSION}

This study has shown that the most commonly detected bacterial genus in most tourist accessible and inaccessible sediment samples of show and control caves was Bacillus (Firmicutes). Although there were differences in the bacteria genera detected in these caves, phylogenetic analysis indicated they belonged to four different groups (Firmicutes, Proteobacteria, Acidobacteria and Actinobacteria). Differences were also observed in the bacterial communities of the tourist accessible show caves compared to that of the control cave. Detection of bacterial groups (commonly found on walls) in sediments suggests that sediments can act as a reservoir of these organisms which might have some implications on cave conservation activities. Differences in the bacterial diversity in show caves have also highlighted the role other factors such as cave use and cave configurations might play in cave bacteria distribution. Further investigations are required with more high impact and multiple activities caves with different management regimes to validate this. In addition, the potential differences in airflow between caves with (closed) and without doors (opened) need to be further investigated especially with respect to bacterial distribution. Changes in microbial diversity can be caused by human access but cave management protocols (for example by constructing doors) may help in controlling the entry of exogenous 
substances and microorganisms into the caves. The benefits of such actions will have to be evaluated in terms of their practicality and effects on the caves microclimatic environment and conservation.

\section{ACKNOWLEDGMENTS}

We acknowledge the support and access provided by the Department of Environment and Natural Resources, South Australia to Naracoorte Caves. We also acknowledge the assistance with the drawing of the maps provided by Robert Keane of the School of Environment, Geography, Population and Environmental Management, Flinders University, South Australia.

\section{REFERENCES}

Adetutu E.M., Thorpe K., Bourne S., Cao X., Shahsavari E., Kirby G. \& Ball A.S., 2011 Phylogenetic diversity of fungal communities in areas accessible and not accessible to tourists in Naracoorte Caves. Mycologia, 103: 959-968. http:/ /dx.doi.org/10.3852/10-256

Barton H.A., 2006- Introduction to cave microbiology: a review for the non-specialist. Journal of Cave and Karst Studies, 68: 43-54.

Barton H.A. \& Jurado V., 2007 - What's up down there? Microbial diversity in caves. Microbe, 2: 132-138.

Baskar S., Baskar R., Tewari V.C., Thorseth I.H., Øvreås L., Lee N.M. \& Routh J., 2011 - Cave Geomicrobiology in India: status and prospects stromatolites: In: Tewari V. \& Seckbach J, (Eds)., Interaction of microbes with sediments, Springer Netherlands, 18: 541-569.

Bastian F., Alabouvette C. \& Saiz-Jimenez C., 2009The impact of arthropods on fungal community structure in Lascaux Cave. Journal of Applied Microbiology, 106: 1456-1462. http://dx.doi.org/10.1111/j.1365-2672.2008.04121.x

Bastian F., Jurado V., Nováková A., Alabouvette C. \& Saiz-Jimenez C., 2010- The microbiology of Lascaux Cave. Microbiology, 156: 644-652. http://dx.doi.org/10.1099/mic.0.036160-0

Campbell J.W., Watson A., Watson C., Ball H. \& Pirkle R., 2011 - Escherichia coli, other coliform, and environmental chemoheterotrophic bacteria in isolated pools from six caves in northern Alabama and northwestern Georgia. Journal of Cave and Karst Studies, 75: 75-82.

http://dx.doi.org/10.4311/jcks2009mb0131

Chelius M.K., Beresford G., Horton H., Quirk M., Selby G., Simpson R.T., Horrocks R. \& Moore J.C., 2009-Impacts of alterations of organic inputs on the bacterial community within the sediments of Wind Cave, South Dakota, USA. International Journal of Speleology, 38: 1-10.

Chelius M.K. \& Moore J.C., 2004 - Molecular phylogenetic analysis of archaea and bacteria in Wind Cave, South Dakota. Geomicrobiology Journal, 21: 123-134. http://dx.doi.org/10.1080/01490450490266389
Dereeper A., Guignon V., Blanc G., Audic S., Buffet S., Chevenet F., Dufayard J.F., Guindon S., Lefort V., Lescot M., Claverie J.M. \&, Gascuel O., 2008 - Phylogeny.fr: robust phylogenetic analysis for the non-specialist. Nucleic Acids Research, 36: W465-W469. http://dx.doi.org/10.1093/nar/gkn180

Fernandez-Cortes A., Calaforra J.M. \& SanchezMartos F., 2006 - Spatiotemporal analysis of air conditions as a tool for the environmental management of a show cave (Cueva del Agua, Spain). Atmospheric Environment, 4: 7378-7394. http://dx.doi.org/10.1016/j.atmosenv.2006.06.045

Fernandez-Cortes A., Cuezva S., Sanchez-Moral S., Cañaveras J., Porca E., Jurado V., MartinSanchez P. \& Saiz-Jimenez C., 2011 - Detection of human-induced environmental disturbances in a show cave. Environmental Science and Pollution Research, 18: 1037-1045.

http://dx.doi.org/10.1007/s11356-011-0513-5

Girvan M.S, Bullimore J., Pretty J.N., Osborn A.M.\& Ball A.S., 2003 - Soil type is the primary determinant of the composition of the total and active bacterial communities in arable soils. Applied and Environmental Microbiology, 69: 1800-1809. http://dx.doi.org/10.1128/AEM.69.3.1800-1809.2003

Gurtner C., Heyrman J., Piñar G., Lubitz W., Swings J. \& Rölleke S., 2000 - Comparative analyses of the bacterial diversity on two different biodeteriorated wall paintings by DGGE and 16S rDNA sequence analysis. International Biodeterioration \& Biodegradation, 46: 229-239.

http://dx.doi.org/10.1016/S0964-8305(00)00079-2

Ikner L.A., Toomey R.S., Nolan G., Neilson J.W., Pryor B.M. \& Maier R.M. 2007 - Culturable microbial diversity and the impact of tourism in Kartchner Caverns, Arizona. Microbial Ecology, 53: 30-42. http:/ / dx.doi.org/10.1007/s00248-006-9135-8

Jurado V., Laiz L., Rodriguez-Nava V., Boiron P., Hermosin B., Sanchez-Moral S. \& SaizJimenez C., 2010 - Pathogenic and opportunistic microorganisms in caves. International Journal of Speleology, 39: 15-24.

Lavoie K.H. \& Northup D.E., 2006 - Bacteria as indicators of human impact in caves. In: Rea G.T. (Ed). 7th National Cave and Karst Management Symposium, Proceedings. Albany, NY: NICKMS Steering Committee: 40-47.

Margesin R. \& Schinner F., 2001 - Biodegradation and bioremediation of hydrocarbons in extreme environments. Applied Microbiology and Biotechnology, 56: 650-663. http://dx.doi.org/10.1007/s002530100701

Martinez A. \& Asencio A.D. 2010 - Distribution of cyanobacteria at the Gelada Cave (Spain) by physical parameters. Journal of Cave and Karst Studies, 72: 11-20.

http://dx.doi.org/10.4311/jcks20091sc0082 
Marzorati M., Wittebolle L., Boon N., Daffonchio D. \& Verstraete W., 2008 - How to get more out of molecular fingerprints: practical tools for microbial ecology. Environmental Microbiology, 10: 15711581. http://dx.doi.org/10.1111/j.1462-2920.2008.01572.x

Mulec J., Kristufek V. \& Chronakova A., 2012 Comparative microbial sampling from eutrophic caves in Slovenia and Slovakia using RIDA ${ }^{\circledR}$ COUNT test kits. International Journal of Speleology, 41:125-136. http://dx.doi.org/10.5038/1827-806X.41.1.1

Muyzer G., De Waal E.C. \&Uitterlinden A.G., 1993 - Profiling of complex microbial populations by denaturing gradient gel electrophoresis analysis of polymerase chain reaction-amplified genes coding for 16S rRNA. Applied and Environmental Microbiology, 59: 695-700.

Osborn A.M., Moore E.R.B. \& Timmis K.N., 2000 - An evaluation of terminal-restriction fragment length polymorphism (T-RFLP) analysis for the study of microbial community structure and dynamics. Environmental Microbiology, 2: 39-50. http://dx.doi.org/10.1046/j.1462-2920.2000.00081.x

Park D.J., Lee S.H., Park H.R., Kwon O.S., Park S.H., Yeo S.H., Uramoto M. \& Kim C.J., 2000 Genus diversity of soil actinomycetes isolated from natural lime caves. Korean Journal of Applied Microbiology and Biotechnology, 28: 129-133.

Pašić L., Kovče B., Sket B. \& Herzog-Velikonja B., 2010 - Diversity of microbial communities colonizing the walls of a Karstic cave in Slovenia. FEMS Microbiology Ecology, 71: 50-60. http://dx.doi.org/10.1111/j.1574-6941.2009.00789.x

Patil S.S., Ward A.J., Kumar M.S. \& Ball A.S., 2010 - Utilising bacterial communities associated with digested piggery effluent as a primary food source for the batch culture of Moina australiensis. Bioresource Technology, 101: 3371-3378. http://dx.doi.org/10.1016/j.biortech.2009.12.030

Pflitsch A. \& Piasecki J., 2003 - Detection of an airflow system in Niedzwiedzia (Bear) Cave, Kletno, Poland. Journal of Cave and Karst Studies, 65: 160-173.

Portillo M., Porca E., Cuezva S., Cañaveras J., Sanchez-Moral S. \& Gonzalez J., 2009a - Is the availability of different nutrients a critical factor for the impact of bacteria on subterraneous carbon budgets? Naturwissenschaften, 96: 1035-1042. http://dx.doi.org/10.1007/s00114-009-0562-5

Portillo M.C., Saiz-Jimenez C. \& Gonzalez J.M., 2009b - Molecular characterization of total and metabolically active bacterial communities of "white colonizations" in the Altamira Cave, Spain. Research in Microbiology, 160: 41-47. http://dx.doi.org/10.1016/j.resmic.2008.10.002
Pulido-Bosch A., Martín-Rosales W., López-Chicano M., Rodríguez-Navarro C.M. \& Vallejos A., 1997 - Human impact in a tourist karstic cave (Aracena, Spain). Environmental Geology, 31: 142-149. http://dx.doi.org/10.1007/s002540050173

Russell M.J. \& MacLean V.L., 2008 - Management issues in a Tasmanian tourist cave: potential microclimatic impacts of cave modifications. Journal of Environmental Management, 87: 474-483.

http://dx.doi.org/10.1016/j.jenvman.2007.01.012

Schabereiter-Gurtner C., Saiz-Jimenez C., Piñar G., Lubitz W. \& Rölleke S., 2002 - Phylogenetic 16S $r R N A$ analysis reveals the presence of complex and partly unknown bacterial communities in Tito Bustillo cave, Spain, and on its Palaeolithic paintings. Environmental Microbiology, 4: 392-400. http://dx.doi.org/10.1046/j.1462-2920.2002.00303.x

Schabereiter-Gurtner C., Saiz-Jimenez C., Piñar G., Lubitz W. \& Rölleke S., 2004 - Phylogenetic diversity of bacteria associated with Paleolithic paintings and surrounding rock walls in two Spanish caves (Llonin and La Garma). FEMS Microbiology Ecology, 47: 235-247.

http://dx.doi.org/10.1016/S0168-6496(03)00280-0

Shapiro J. \& Pringle A., 2010 - Anthropogenic influences on the diversity of fungi isolated from caves in Kentucky and Tennessee. The American Midland Naturalist, 163: 76-86.

http://dx.doi.org/10.1674/0003-0031-163.1.76

Stomeo F., Portillo M.C. \& Gonzalez J.M., 2009 Assessment of bacterial and fungal growth on natural substrates: consequences for preserving caves with prehistoric paintings. Current Microbiology, 59: 321-325.

http://dx.doi.org/10.1007/s00284-009-9437-4

Urzi C., De Leo F., Bruno L. \& Albertano P., 2010 - Microbial diversity in Paleolithic caves: a study case on the phototrophic biofilms of the Cave of Bats (Zuheros, Spain). Microbial Ecology, 60: 116-129.

http:/ /dx.doi.org/10.1007/s00248-010-9710-x

Vaughan M.J., Maier R.M. \& Pryor B.M., 2011 - Fungal communities on speleothem surfaces in Kartchner Caverns, Arizona, USA. International Journal of Speleology, 40: 65-77.

http://dx.doi.org/10.5038/1827-806X.40.1.8

Zhou J., Gu Y., Zou C. \& Mo M., 2007 - Phylogenetic diversity of bacteria in an earth-cave in Guizhou Province, Southwest of China. Journal of Microbiology, 45: 105-112. 